\title{
Original
}

\section{Effects on Plaque Acidogenicity of Salivary Factors and Frequency of Between-Meal Eating}

\author{
歯垢の酸産生能に及ぼす唾液要因および \\ 間食摂取頻度の影響について
}

\author{
Itsuo UEDA*, Hideo ANBE* and Shunichi NAKAO* \\ 上田五 男* 安 倍 英 雄* 中尾俊 -*
}

Received November 20, 1985 ; accepted December 6, 1985

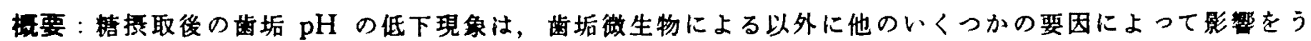

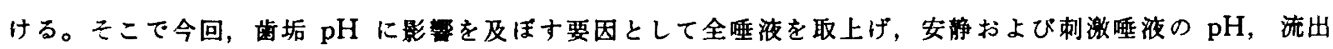

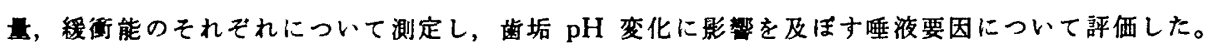

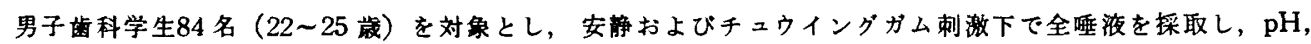
flow rate, buffer capacity を测定するとともに，Lactobacilli およびS. mutans の菌数算定を行った。ま た，特定齿面から齿垢を可及的に一定量探取し，in vitro において $8 \%$ \%ニクロース溶液を基梊として15分 間培䅈し,この結果を歯垢の酸産生能の指標とした。

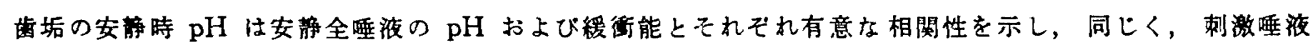
の $\mathrm{pH}$ および悢街能とも統計学的有意な相関関倸を示した。

画垢の酸産生能 (final $\mathrm{pH}$ ) と安静唾液の $\mathrm{pH}$ および緩衙能との間には有意な相関関係が得られた。しか し，刺激液の $\mathrm{pH}$ および楥衙能との問には有意な相関性が認められなかった。なお刺激喠液中のLactoba cilli とS. mutans 菌数注, 両者とも苗垢の酸産生能と密接に関連することが見出された。

一方，啠問票による問食回数の調查結果と苗垢の酸産生能との間には統計学的有意な正の相関関保が珰め られた。

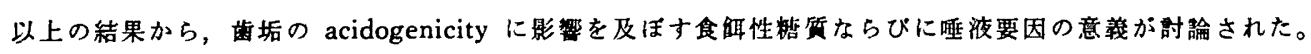

Koy words: Plaque acidogenicity, Salivary factors, Between-meal frequency, S. mutans, Lactobacilli

索引用語 : 蒾恬の酸産生能, 唾液要因, 間食回数, S. mutans, Lactobacilli

\section{Introduction}

It is generally accepted that the immediate attack agents of dental caries are acids produced by dental plaque adhering to specific enamel surfaces. When various carbohydrates are ingested, a rapid decrease in plaque $\mathrm{pH}$ occurs following the production of organic acids by plaque bacteria followed by a slow gradual rise to the initial $\mathrm{pH}$ level. These changes in the $\mathrm{pH}$ of plaque are modified by the flow and composition of the oral fluids and may be influenced not only by the plaque flora itself but also by

* Department of Dental health Josai Dental University (Chief: Prof. Shunichi NAKAO)

* 城西齿科大学口腔衙生学教室（主任: 中尾伐一教授）

特別揭载 
many other factors ${ }^{1}$.

The relationship between saliva, plaque and caries had been extensively discussed ${ }^{2-4}$. However, how each of salivary factors influences the $\mathrm{pH}$ changes in plaque has not yet been critically assessed.

In the present report, we determined some salivary factors, i.e., pH, flow rate, and buffer effect, and attempted to analyze the relationship between each of the salivary parameters and plaque acidogenicity in vitro. In addition, we determined the numbers of Lactobacilli and Streptococcus mutans in saliva and analyzed the relation between their levels and the plaque $\mathrm{pH}$.

Furthermore, we tried to evaluate the relative importance of the salivary factors and to get some information about the dynamic caries process in relation to saliva-plaque interactions.

\section{Materials and Methods}

Subjects : 84 male dental students aged 22-25 participated in this study. They were instructed to refrain from oral hygiene for one day. Tooth prophylaxis was not performed before the collection period started.

Plaque material : Plaque samples were collected from the buccal interdental areas of upper molars with the aid of a Gracy type curette under moisture control with cotton rolls.

Assessment of plaque acid production: The plaque activity was evaluated by measuring the $\mathrm{pH}$ of plaque collected in a sucrose solution in vitro. The materials and methods used in plaque $\mathrm{pH}$ determination have been reported elesewhere ${ }^{5)}$. Briefly, the reaction mixture contained approximately $1 \mathrm{mg}$ plaque in an $8 \%$ sucrose solution, total volume being $200 \mu l$. This was incubated aero bically for fifteen minutes at $36.5^{\circ} \mathrm{C}$. The initial and final $\mathrm{pH}$ of the medium were read from a $\mathrm{pH}$ meter.

Saliva sample: The collection of saliva was performed between 10 and 11 a.m. Individual saliva samples were collected during the so-called resting state (collection time, $10 \mathrm{mins}$ ) and during the mastication of a bolus of sugarless chewing gum. Before collecting resting saliva, the subjects were asked to rinse once with $10 \mathrm{ml}$ of distilled water and to expectorate the fluid in the mouth into a graduate chilled test tube.

Then, after the initial oral conditions were standardized by having the subjects chew a bolus of sugarless gum for one min, stimulated saliva was collected during the mastication of the chewing gum for $2 \mathrm{~min}$.

Immediately after the saliva was collected, the $\mathrm{pH}$, flow rate, and buffer effect were assessed. Buffer effect was evaluated by the buffer $\mathrm{pH}$ method $^{(1)}$. Briefly, the resulting $\mathrm{pH}$ of the saliva when $2.0 \mathrm{~m} l$ of saliva is titrated against $0.3 \mathrm{~m} l$ of $0.1 \mathrm{~N}$ lactic acid represents the buffer effect.

Microbiological procedures: The saliva samples were dispersed by using a Whirlimixer ${ }^{\circledR}$ for 60 sec and then diluted to $10^{-1}$. One $\mathrm{ml}$ of the saliva samples was then taken and diluted in 10-fold steps with a $0.45 \%$ sodium chloride solution. From each dilution, $0.1 \mathrm{~m} l$ was taken with a micropipette and cultured on Rogosa SL agar (Difco) for Lactobacilli and on MSB-agar for S. mutans ${ }^{7}$.

All plates were incubated for $48 \mathrm{~h}$ at $37^{\circ} \mathrm{C}$ in $90 \% \mathrm{~N}_{2}, 5 \% \mathrm{CO}_{2}$ and $5 \% \mathrm{H}_{2}$ (GasPac, BBL). The identification of $S$. mutans was confirmed by colony morphology and sugar fermentation tests. The saliva levels of both organisms were expressed as colony forming units (CFU) per $\mathrm{m} l$ saliva.

Clinical examination: The subjects were examined and scored for caries. The diagnosis of caries was made with mirror and explorer based on the WHO criteria for clinical caries ${ }^{8)}$.

Dietary questionnaire : A dietary questionnaire was given to each subject. The respondent recorded his frequency of between-meal snacks and/or beverages ingested during the ordinary entire day. The frequency pattern of subjects was scored on a progressive scale of 1 (none), 2 (once), 3 (2-3 times) and 
Table 1 Plaque initial and final $\mathrm{pH}$ 's at different Lactobacilli levels of stimulated whole saliva

\begin{tabular}{|c|c|c|c|c|}
\hline \multirow{2}{*}{ Plaque $\mathrm{pH}$} & \multicolumn{4}{|c|}{ Lactobacilli $($ CFU $/ \mathrm{m} l)$} \\
\hline & $\mathrm{ND}$ & $10^{3}$ & $10^{4}$ & $10^{5} \leq$ \\
\hline \multirow[t]{2}{*}{ initial } & $6.38^{1)}$ & 6.34 & 6.31 & 6.22 \\
\hline & \pm 0.30 & \pm 0.28 & \pm 0.21 & \pm 0.27 \\
\hline \multirow[t]{2}{*}{ final } & 5.59 & 5.31 & $5.25^{* *}$ & $5.15^{* * *}$ \\
\hline & \pm 0.47 & \pm 0.56 & \pm 0.53 & \pm 0.59 \\
\hline difference & $\mathrm{pH} 0.79$ & 1.03 & 1.06 & 1.07 \\
\hline
\end{tabular}

1) mean \pm S. D.

* ND : not detected $\left(<10^{8} \mathrm{CFU} / \mathrm{m} l\right.$ saliva) ${ }^{* *} \mathrm{P}<0.05 \quad{ }^{* * *} \mathrm{P}<0.01$

4 (more than 4 times).

Statistical analysis : The statistical significance of the difference between the two means was tested using Student's $t$-test. The relationship between the two variables was estimated by linear correlation analysis.

\section{Results}

The mean of initial plaque $\mathrm{pH}$ and that of final $\mathrm{pH}$ following a $15-\mathrm{min}$ incubation with a sucrose solution in 84 subjects were $\mathrm{pH} 6.32 \pm$ $0.26(\mathrm{SD})$ and $\mathrm{pH} 5.32 \pm 0.56$, respectively.

Table 1 shows the mean final $\mathrm{pH}$ corresponding to the order of $\mathrm{CFU} / \mathrm{ml}$ of Lactobacilli in saliva. The relationship between the salivary concentration of $S$. mutans and the final plaque $\mathrm{pH}$ is shown in Table 2. These results clearly
Table 2 Plaque initial and final $\mathrm{pH}$ 's at different $S$. mutans levels of stimulated whole saliva

\begin{tabular}{|c|c|c|c|c|}
\hline \multirow{2}{*}{ Plaque $\mathrm{pH}$} & \multicolumn{4}{|c|}{ Strep. mutans $(\mathrm{CFU} / \mathrm{m} l)$} \\
\hline & $\leq 10^{3}$ & $10^{4}$ & $10^{5}$ & $10^{6}$ \\
\hline \multirow[t]{2}{*}{ initial } & $6.41^{1)}$ & 6.33 & 6.23 & 6.27 \\
\hline & \pm 0.27 & \pm 0.26 & \pm 0.27 & \pm 0.13 \\
\hline \multirow[t]{2}{*}{ final } & 6.02 & $5.44^{*}$ & $5.17^{* *}$ & $5.07^{* x}$ \\
\hline & \pm 0.23 & \pm 0.50 & \pm 0.62 & \pm 0.43 \\
\hline difference ${ }^{1)}$ & $\mathrm{pH} \quad 0.39$ & 0.89 & 1.06 & 1.20 \\
\hline
\end{tabular}

1) mean \pm S. D.

${ }^{*} \mathrm{P}<0.01 \quad * * \mathrm{P}<0.001$

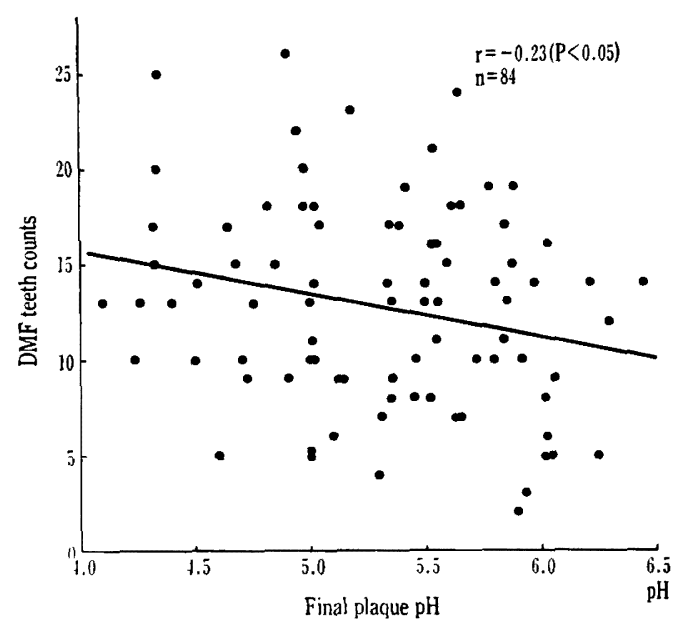

Fig. 1 The relation between plaque $\mathrm{pH}$ after a $15 \mathrm{~min}$. incubation and caries occurrence. indicate that the acidogenicity of the dental plaque in the present in vitro system increased with increasing orders of CFU/ml of both bacteria in stimulated whole saliva. The differences in final $\mathrm{pH}$ between the order of $10^{3} \mathrm{CFU} / \mathrm{m} l$ or less and those of $10^{4} \mathrm{CFU} / \mathrm{ml}$, and $10^{5} \mathrm{CFU} / \mathrm{ml}$ or more of Lactobacilli in saliva were statistically significant. For S. mutans, the differences between the final $\mathrm{pH}$ of $10^{8} \mathrm{CFU} / \mathrm{m} l$ or less and those of $10^{4}, 10^{5}$ and $10^{8}$ or more were also statistically significant.

The data showed a weak negative correlation between the final $\mathrm{pH}$ of plaque and the numbers of DMFT, indicating that the plaque $\mathrm{pH}$ response to sucrose reflected increased caries occurrence (Fig. 1).

The relationship between plaque $\mathrm{pH}$ and each of the salivary factors is shown in Table 3 . The correlation between the plaque initial $\mathrm{pH}$ and the resting saliva $\mathrm{pH}$ and buffer effect was statistically significant. Likewise, the plaque initial $\mathrm{pH}$ was positively correlated with each of the stimulated saliva $\mathrm{pH}$ and buffer effects. On the other hand, the plaque final $\mathrm{pH}$ was positively correlated with the resting saliva $\mathrm{pH}$ and buffer effect. The plaque final $\mathrm{pH}$ was positively related to the stimulated saliva $\mathrm{pH}$ and 
Table 3 Correlations between plaque $\mathrm{pH}$, and $\mathrm{pH}$, buffer $\mathrm{pH}$ and flow rate in resting and stimulated whole saliva

\begin{tabular}{|c|c|c|c|c|c|c|}
\hline \multirow{2}{*}{ Plaque } & \multicolumn{3}{|c|}{ Resting saliva } & \multicolumn{3}{|c|}{ Stimulated saliva } \\
\hline & $\mathrm{pH}$ & buffer $\mathrm{pH}$ & flow rate & $\mathrm{pH}$ & buffer $\mathrm{pH}$ & flow rate \\
\hline initial $\mathrm{pH}$ & $0.30^{* * *}$ & $0.27^{* *}$ & 0.09 & $0.25^{* *}$ & $0.25^{* *}$ & 0.08 \\
\hline \multirow[t]{2}{*}{ final $\mathrm{pH}$} & $0.33^{* * * *}$ & $0.31^{* * *}$ & 0.03 & $0.21^{*}$ & $0.19^{*}$ & $0.23^{*}$ \\
\hline & 0.10 & $<0.02$ & $P<0.01$ & $<0.001$ & & \\
\hline
\end{tabular}

Table 4 Plaque final $\mathrm{pH}$ and between-meal frequency

\begin{tabular}{|c|c|c|c|c|}
\hline & \multicolumn{4}{|c|}{ Between-meal frequency } \\
\hline & 0 & 1 & $2 \sim 3$ & $4 \leq$ \\
\hline \multirow[t]{2}{*}{ Plaque final $\mathrm{pH}$} & $5.52^{1)}$ & 5.43 & 5.31 & 5.03 \\
\hline & \pm 0.30 & \pm 0.59 & \pm 0.55 & \pm 0.56 \\
\hline $\mathrm{n}$ & 4 & 22 & 48 & 10 \\
\hline
\end{tabular}

Table 5 Correlations between plaque $\mathrm{pH}$ and between-meal frequency

\begin{tabular}{|c|c|}
\hline Plaque $\mathrm{pH}$ & Between-meal frequency \\
\hline initial & -0.13 \\
\hline final & $-0.21^{*}$ \\
\hline
\end{tabular}

buffer effect, but a statistical significance was not obtained in either. Table 4 shows the mean values of plaque final $\mathrm{pH}$ according to the reported frequency of between-meal snacks and/or sugar-containing beverages. The final $\mathrm{pH}$ decreased with the increase in the frequency. Table 5 shows the coefficients of correlation between the between-meal frequency and the plaque resting and final $\mathrm{pH}$. The relation of the frequency to the plaque final $\mathrm{pH}$ was statistically significant.

A direct relationship between the initial and final $\mathrm{pH}$ of the plaque was found $(\mathrm{r}=0.37 ; \mathrm{P}<0.01$; data not shown).

\section{Discussion}

Stephan ${ }^{9 !}$ demonstrated that a drop in plaque $\mathrm{pH}$ occurred after the ingestion of certain refined carbohydrates, and furhter he showed that $\mathrm{pH}$ minimum levels in plaque were inversely related to the caries activity in individuals ${ }^{10)}$. Englander et al. ${ }^{11}$ determined $\mathrm{pH}$ of dental plaque from the buccal surfaces of upper molars in vitro before and at varied minutes following a sucrose oral spray with and without saliva restriction, and noted the importance of saliva in preventing plaque $\mathrm{pH}$ values from falling below the level of $\mathrm{pH} 5.5$.

We believe that the intensity and duration of the $\mathrm{pH}$ decrease depends not only on the plaque flora but also on the composition and frequency of the diet and on endogenous factors.

In the present study we have shown that the final plaque $\mathrm{pH}$ following a sucrose exposure is positively correlated with the $\mathrm{pH}$ and the buffer effect of resting saliva. Edgar ${ }^{12}$ found a positive relation of the resting plaque $\mathrm{pH}$ and the minimum $\mathrm{pH}$ reached after sugar mouth rinse to the resting saliva $\mathrm{pH}$ levels. But the statistical significance of the correlation between the minimum $\mathrm{pH}$ and the resting saliva $\mathrm{pH}$ was not conclusive $(\mathrm{P}<0.1)$. From the relationships observed between the Stephan curves and the salivary responses, Edgar et al. ${ }^{13)}$ suggested that the $\mathrm{pH}$ of saliva is a major factor controlling plaque $\mathrm{pH}$. The present study showed that the resting plaque $\mathrm{pH}$ was significantly correlated with the resting and the stimulated saliva $\mathrm{pH}$, and moreover correlated with both salivary buffers (Table 3 ). 
Recently, Tatevossian ${ }^{10}$ showed that the difference between buffering in plaque fluid and saliva is quantitatively smaller above $\mathrm{pH} 6$ and that the irreversible loss of buffer capacity above $\mathrm{pH} 6$ may be due to loss of bicarbonate as $\mathrm{CO}_{2}$ during the acid titration. He suggested that the salivary contamination of plaque can determine the buffering capacity of plaque in the range above $\mathrm{pH} 6^{14}$, which, in turn, influences the $\mathrm{pH}$ lowering ability of plaque.

In this study, the final $\mathrm{pH}$ of plaque indicated a tendency toward a positive relation to the $\mathrm{pH}$, buffer capacity, and flow rate of stimulated saliva. Especially, there was a relatively high value of correlation coefficient between the final $\mathrm{pH}$ of plaque and the flow rate. This may suggest direct and/or indirect effects on the amount and the composition of plaque of stimulated whole saliva. But the mechanism of this is not clear.

Kleinberg and Jenkins ${ }^{15)}$ observed that the $\mathrm{pH}$ of dental plaque in the different areas of mouth before and after meals reflected the flow and $\mathrm{pH}$ of resting saliva.

The present data further showed that the final $\mathrm{pH}$ of plaque was significantly related to the numbers of $S$. mutans and those of Lactobacilli in saliva.

Stralfors ${ }^{16)}$ found an inverse relationship between the $\mathrm{pH}$ minima produced by the ingestion of glucose and the Lactobacilli counts in the plaque on the maxillary anterior teeth. For S. mutans, Edga et al. ${ }^{13)}$ showed that an acidic Stephan curve characterized by a low resting $\mathrm{pH}$ and a low minimum $\mathrm{pH}$ is associated with higher numbers of $S$. mutans in plaque. McNamara et al. ${ }^{17)}$ observed that Lactobacilli were mainly found in the maxillary anterior approximal plaque, whereas the less acid Streptococci usually occurred in the labial maxillary anterior plaque.

In a human study, van Houte and Green ${ }^{18)}$ reported that the mean salivary concentration of naturally occurring S. mutans and Lactobacilli was $3.7 \times 10^{5}$ and $3.8 \times 10^{5} \mathrm{CFU}$ per $\mathrm{ml}$, respectively, and that both bacteria were highly localized on teeth.

Recent evidence suggests that the saliva level of $S$. mutans reflects the prevealence and proportion of this microorganism on the selected tooth surfaces ${ }^{18,20)}$. On the other hand, Schei et al. ${ }^{21}$ from an investigation of the effect of orthodontic treatment on the prevalence of $S$. mutans, concluded that creation of new retentive areas favors the local growth of the bacteria, which in turn increases the general infection level of this organism. In this respect, no significant correlation between the DMFT counts and the numbers of $S$. mutans and Lactobacilli in saliva has been obtained in this study. The orthodontic band placement has also been shown to induce a lowered resting $\mathrm{pH}$ of human incisor tooth plaque ${ }^{222}$.

There are numerous reports which indicate that frequent consumption of various fermentable carbohydrates (mainly, sucrose) can create an environment favorable to Lactobacilli as well as to $S$. mutans $^{23-26)}$. From our dietary questionnaire, we found a significant positive correlation between frequency of between-meal eating and the $\mathrm{pH}$ lowering capacity of plaque. In general, dietary pattern influences the amount and type of plaque formation and the relative numbers of microorganisms on tooth surfaces. It has already been shown that the acidogenic compositon of plaque reflects the dietary habits and caries status of an individual ${ }^{27)}$. Griffiths ${ }^{28)}$ showed that caries-free students had a significantly lower proportion of acidogenic organisms in their plaque than did caries-prone individuals and that this reduction was reflected in a lower rate of glycolysis. As such, it is conceivable that the changes in dietary pattern could influence the acid producing activity of plaque, perhaps by inducing the sucrose-splitting enzymes ${ }^{29}$. Invertase-like activity of dental plaque and oral fluid can be considered as an indicator of the cariogenicity of dental plaque in the presence of sucrose-containing diets ${ }^{30)}$. Even so, it should not be ignored that the dietary habits could affect the response of salivary factors. However, the effect of diet on saliva is not yet definitive. Dawes ${ }^{31)}$ stated that the immediate local reflex effects of a diet on salivary flow rate 
must be distinguished from the systemic effects of salivary flow rate on composition, which may take some time to develop. Tenovuo and Rekola ${ }^{30}$ ) observed a temporary drop in salivary $\mathrm{pH}$ and a decrease in oxidation-reduction potential of whole saliva after consumption of acid-containing beverages. It appears that the degree of functional stimulation of salivary glands by dietary intake may determine salivary flow rate $^{31)}$ which related to the $\mathrm{pH}$ and buffect effect of saliva. Thus, it can be stated that the individual dietary habits may in part determine the levels of salivary $\mathrm{pH}$ and buffer effect and that their effects on saliva may be prolonged or temporary.

A low $\mathrm{pH}$ oral environment may promote the growth of $S$. mutans ${ }^{25)}$ and also favor Lactobacilli ${ }^{32)}$. The present results could provide information concerning the possible relations of salivary and dietary factors with the plaque $\mathrm{pH}$ response to a sugar exposure.

\section{References}

1) Stephan, R. M. : The dental plaque in relation to the etiology of caries. Int. dent. J., 4 ; 180-195, 1953.

2) Mandel, I. D. : Relation of saliva and plaque to caries. J. dent. Res. 53 : suppl., 2 ; 246-266, 1974.

3) Van Houte, J.: Bacterial specificity in the etiology of dental caries. Int. dent. J., 30 ; 305-326, 1980.

4) Kleinberg, I. : Etiology of dental caries. J. Can. dent. Ass., 45 ; 661-668, 1979.

5) Ueda, I., Anbe, H., Yasui, T., Azewaki, R., Himi, K., Nakao, S.: An evaluation of acidogenesis of human plaque in vitro. Bull. Josai dent. Univ., 11 ; 426-433, 1982.

6) Ueda, I., Anbe, H., Nako, S.: A rapid clinical evaluation of salivary buffer $\mathrm{pH}$. J. dent. Health., 34 ; 193-207, 1984.

7) Gold, O. G., Jordan, H. V., van Houte, J.: A selective medium for Streptococcus mutans. Archs oral Biol., $18 ; 1357-1364$, 1973.

8) WHO : Oral health surveys, basic method (World Health Organization, Geneva 1977).

9) Stephan, R. M.: Changes in hydrogen-ion concentration on tooth surfaces and in carious lesions. J. Am. dent. Ass., 27 ; 718-723, 1940.

10) Stephan, R. M. : Intra-oral hydrogen-ion concentrations associated with dental caries activity. J. dent. Res., 23 ; 257-266, 1944.

11) Englander, H. R., Shklair, I. L., Fosdick, L. S.: The effects of saliva on the $\mathrm{pH}$ and lactate concentration in dental plaques. 1. caries-rampant individuals. J. dent. Res, 38 ; 848-853, 1959.

12) Edgar, W. M. : The role of saliva in the control of $\mathrm{pH}$ changes in human dental plaque. Caries Res., 10 ; 241-254, 1976
13) Edgar, W. M., Vernazza, T., Kanapka, J., Pitts, G. : Relationship between plaque $\mathrm{pH}$ and Streptococcus mutans in dental plaque. J. dent. Res., 60 ; 428, 1981.

14) Tatevossian, A.: Buffering capacity in human dental plaque fluid. Caries Res., 11 ; 216-222, 1977.

15) Kleinberg, I., Jenkins, G. N.: The pH of dental plaques in the different areas of the mouth before and after meals and their relationship to the $\mathrm{pH}$ and rate of flow of resting saliva. Archs oral Biol., 9 ; 493-516, 1964.

16) Strálfors, A.: An investigation into the bacterial chemistry of dental plaques. Odont. Tidskr., 58 ; 155-341, 1950.

17) McNamara, T. F., Friedman, B. K., Kleinberg, I. : The microbial composition of human incisor tooth plaque. Archs oral Biol., 24 ; 91-95, 1979.

18) Van Houte, J., Green, D. B. : Relationship between the concentration of bacteria in saliva and the colonization of teeth in humans. Infect. Immun., 9;624-630, 1974.

19) Köhler, B., Pettersson, B.-M., Bratthall, D. : Streptococcus mutans in plaque and saliva and the development of caries. Scand. J. Dent. Res., 89 ; 19-25, 1981.

20) Klock, B. and Krasse, B. : A comparison between different methods for prediction of caries activity. Scand. J. Dent. Res., 87 ; 129-139, 1979.

21) Scheie, A. A., Arneberg, P., Krogstad, O. : Effect of orthodontic treatment on prevalence of Streptococcus mutans in plaque and saliva. Scand. J. dent. Res., 92 ; 211-217, 1984.

22) Chatterjee, R. and Kleinberg, I. : Effect of orthodontic band placement on the chemical composition of human incisor tooth plaque. Archs. Oral Biol., 24 ; 97-100, 1979.

23) Jay, P. : The reduction of oral Lactobacillus counts by the periodic restriction of car- 
bohydrate. Am. J. Orthod., 33 ; 162-184, 1947.

24) Jay, P.: The effect of substrate on the oral flora. J. Am. dent. Ass., 37 ; 416-418, 1948.

25) Svanberg, M.: Streptococcus mutans in plaque after mouthrinsing with buffers of varying $\mathrm{pH}$ value. Scand. J. dent. Res., 88 ; $76-78,1980$.

26) Littleton, N. W., McCabe, R.W., Carter, C. H.: Studies of oral health in persons nourished by stomach tube. II. Acidogenic properties and selected bacterial components of plaque material. Archs oral Biol., 12; 601-609, 1967.

27) Hayes, M. L., Carter, E. C., Griffiths, S. J.: The acidogenic microbial composition of dental plaque from caries-free and cariesprone people. Archs oral Biol., 28 ; 381386, 1983.

28) Griffiths, S. J.: The acidogenic potential of plaque from caries-free and caries-prone subjects and the effects of nonanoate-glucose mouthrinses. Br. dent. J., ; 147 329-331, 1979.

29) Birkhed, D. and Frostell, G. : Influence of sucrose concentration on production of organic acids, soluble polysaccharides and reducing sugars in human dental plaque in vitro. Caries Res., 12 ; 183-189, 1978.

30) Tenovuo, J., Rekola, M.: Some effects of sugar-flavored acid beverages on the biochemistry of human whole saliva and dental plaque. Acta odont. scand., $35 ; 317-330$, 1977.

31) Dawes, C.: Effects of diet on salivary secretion and composition. J. dent. Res., 49 ; 1263-1272, 1970.

32) Crossner, C.G.: Variation in human oral Lactobacilli following a change in sugar intake. Scand. J. dent. Res., 92 ; 204-210, 1984. 